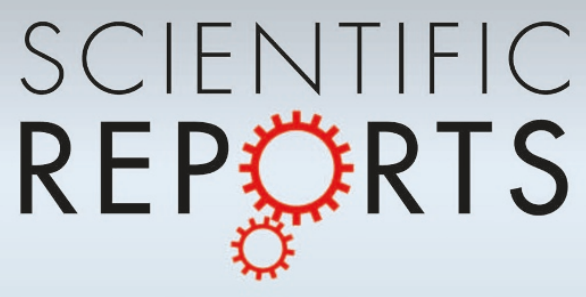

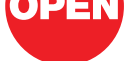

SUBJECT AREAS: PHYSICAL OCEANOGRAPHY

ATMOSPHERIC DYNAMICS

EARTH AND ENVIRONMENTAL SCIENCES

CLIMATE-CHANGE IMPACTS

Received

1 October 2012

Accepted

25 January 2013

Published

14 February 2013

Correspondence and requests for materials should be addressed to M.F. (ming.feng@ csiro.au)

\section{La Niña forces unprecedented Leeuwin Current warming in 2011}

\author{
Ming Feng ${ }^{1}$, Michael J. McPhaden ${ }^{2}$, Shang-Ping Xie ${ }^{3,4} \&$ Jan Hafner ${ }^{3}$
}

'CSIRO Marine and Atmospheric Research, Floreat, Western Australia, Australia, ${ }^{2}$ Pacific Marine Environmental Laboratory, National Oceanic and Atmospheric Administration, Seattle, Washington, USA, ${ }^{3}$ International Pacific Research Center, University of Hawaii, Honolulu, Hawaii, USA, ${ }^{4}$ Scripps Institution of Oceanography, University of California at San Diego, La Jolla, California, USA.

Unprecedented warm sea surface temperature (SST) anomalies were observed off the west coast of Australia in February-March 2011. Peak SST during a 2-week period were $5^{\circ} \mathrm{C}$ warmer than normal, causing widespread coral bleaching and fish kills. Understanding the climatic drivers of this extreme event, which we dub "Ningaloo Niño", is crucial for predicting similar events under the influence of global warming. Here we use observational data and numerical models to demonstrate that the extreme warming was mostly driven by an unseasonable surge of the poleward-flowing Leeuwin Current in austral summer, which transported anomalously warm water southward along the coast. The unusual intensification of the Leeuwin Current was forced remotely by oceanic and atmospheric teleconnections associated with the extraordinary 2010-2011 La Niña. The amplitude of the warming was boosted by both multi-decadal trends in the Pacific toward more La Niña-like conditions and intraseasonal variations in the Indian Ocean.

W ater temperatures affect the growth, survival, abundance and distribution of most marine species ${ }^{1-3}$. Rapid short-term temperature rises can be harmful or even lethal to marine organisms, as in the case coral bleaching and fish mortality ${ }^{4-7}$, and have potentially catastrophic impacts on marine ecosystems throughout the world's oceans ${ }^{8,9}$. In early 2011, an unprecedented extreme warming event (also referred to as a "marine heat wave") was observed off the west coast of Australia in the southeast Indian Ocean at the peak of 2010-2011 La Niña ${ }^{10,11}$. The marine heat wave had profound impacts on marine ecosystem structure in this global biodiversity hotspot, including massive fish and invertebrate kills and coral bleaching along the coast ${ }^{10-15}$. It is essential to document and understand the climatic drivers of this extreme event, which we dub "Ningaloo Niño" (more details in the Discussion section), in order to prepare for a future in which similar events may occur more frequently under global warming.

Ocean circulation off the west coast of Australia is dominated by the Leeuwin Current, a poleward-flowing eastern boundary current that transports warm tropical waters to the south ${ }^{16}$. Interannual variations of the Leeuwin Current are essentially driven by equatorial Pacific easterly wind anomalies related to El Niño Southern Oscillation events ${ }^{17,18}$, which subsequently drive interannual sea surface temperature (SST) variations off the west coast of Australia ${ }^{19}$. Whereas extreme warming events were often forced by air-sea exchanges ${ }^{20}$, we demonstrate in this study that the 2011 marine heat wave off the west coast of Australia was primarily forced by unusual ocean advection in the Leeuwin Current at the peak of the 2010-2011 La Niña.

\section{Results}

Indian Ocean basin warming in mid 2010, which induced strong easterly wind anomalies in the equatorial western Pacific, played an important role in the fast phase transition from a warm pool El Niño to La Niña conditions in the Pacific ${ }^{21}$ (Fig. S1). The 2010-2011 La Niña was a strong event considering the magnitude of the SST anomalies in the Niño 3.4 region of the equatorial Pacific $\left(5^{\circ} \mathrm{N}-5^{\circ} \mathrm{S}, 120^{\circ}-170^{\circ} \mathrm{W}\right)$ in December $2010-$ February 2011 (Fig. 1a). The Southern Oscillation Index (SOI) averaged between July 2010 and April 2011 was about +20 (Fig. 1a) and an SOI-based categorization would classify this event as the second-strongest event of the past century (following 1917) 22 $^{22}$ Associated with the evolution of the La Niña, easterly wind stress anomalies in the equatorial western Pacific were observed to reach unusually high magnitudes of $\sim 0.03 \mathrm{~N} \mathrm{~m}^{-2}$ towards the end of 2010 (Fig. 1b).

In the tropical western Pacific, positive sea level anomalies of 0.2-0.3 m resulted from the easterly wind stress anomalies and associated wind stress curls in late 2010 to early 2011, as evident in a data assimilating model and satellite altimeter observations (Fig. 2b; Fig. S2). Following the equatorial and coastal waveguides, high sea level 

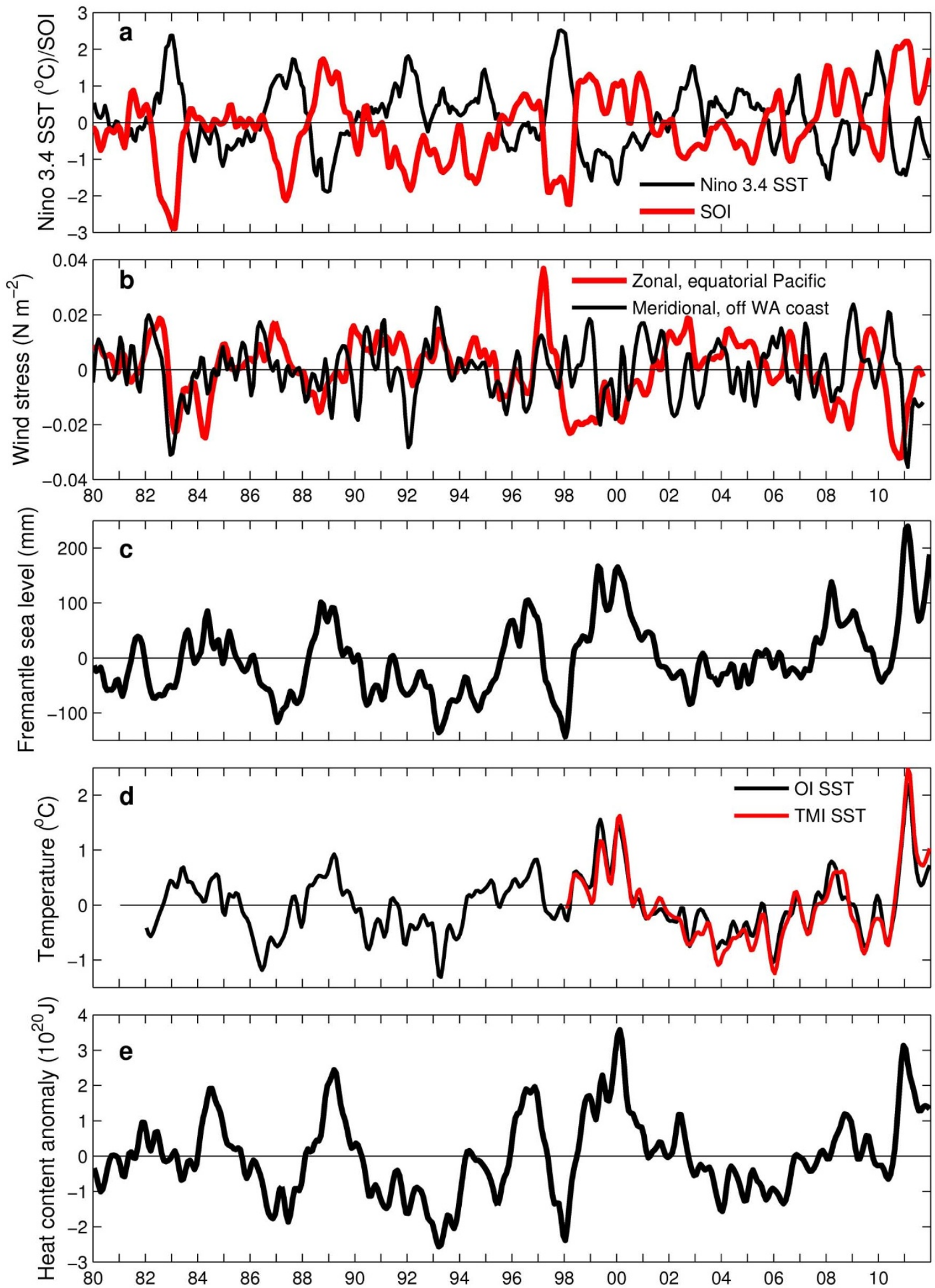

Figure 1 Monthly time series of key indices. (a), Niño 3.4 area sea surface temperature and Southern Oscillation Index (scaled down by a factor of 10). (b), zonal wind stress anomalies averaged over $3^{\circ} \mathrm{S}-3^{\circ} \mathrm{N}, 130-160^{\circ} \mathrm{E}$ in the equatorial Pacific, where the zonal wind anomalies lead the Fremantle sea level on interannual time scales, and meridional wind stress anomalies off the west coast of Australia averaged over $30^{\circ}-22^{\circ} \mathrm{S}, 110^{\circ}-116^{\circ} \mathrm{E}$, as derived from the Tropflux product. (c), Fremantle sea level anomalies, as an index of the strength of the Leeuwin Current off the west coast of Australia.

(d), Sea surface temperature anomalies averaged over $32-26^{\circ} \mathrm{S}, 112-115^{\circ} \mathrm{E}$ off the west coast of Australia (where the interannual temperature variation is largely responding to the Leeuwin Current heat transport), derived from the OISST. (e), Upper ocean (0-150 m) heat content anomalies off northwest Australia $\left(22^{\circ}-15^{\circ} \mathrm{S}, 108^{\circ}-114^{\circ} \mathrm{E}\right)$, the key forcing region of the Leeuwin Current, derived from GODAS reanalysis. The red curve in (d) is derived from TMI SST product. Anomalies in (b), (c), (d) and (e) are smoothed with a 5-point Hanning filter. A linear trend of 1.6 mm per year has been removed from the Fremantle sea level to account for the global sea level rising trend during the past century. 

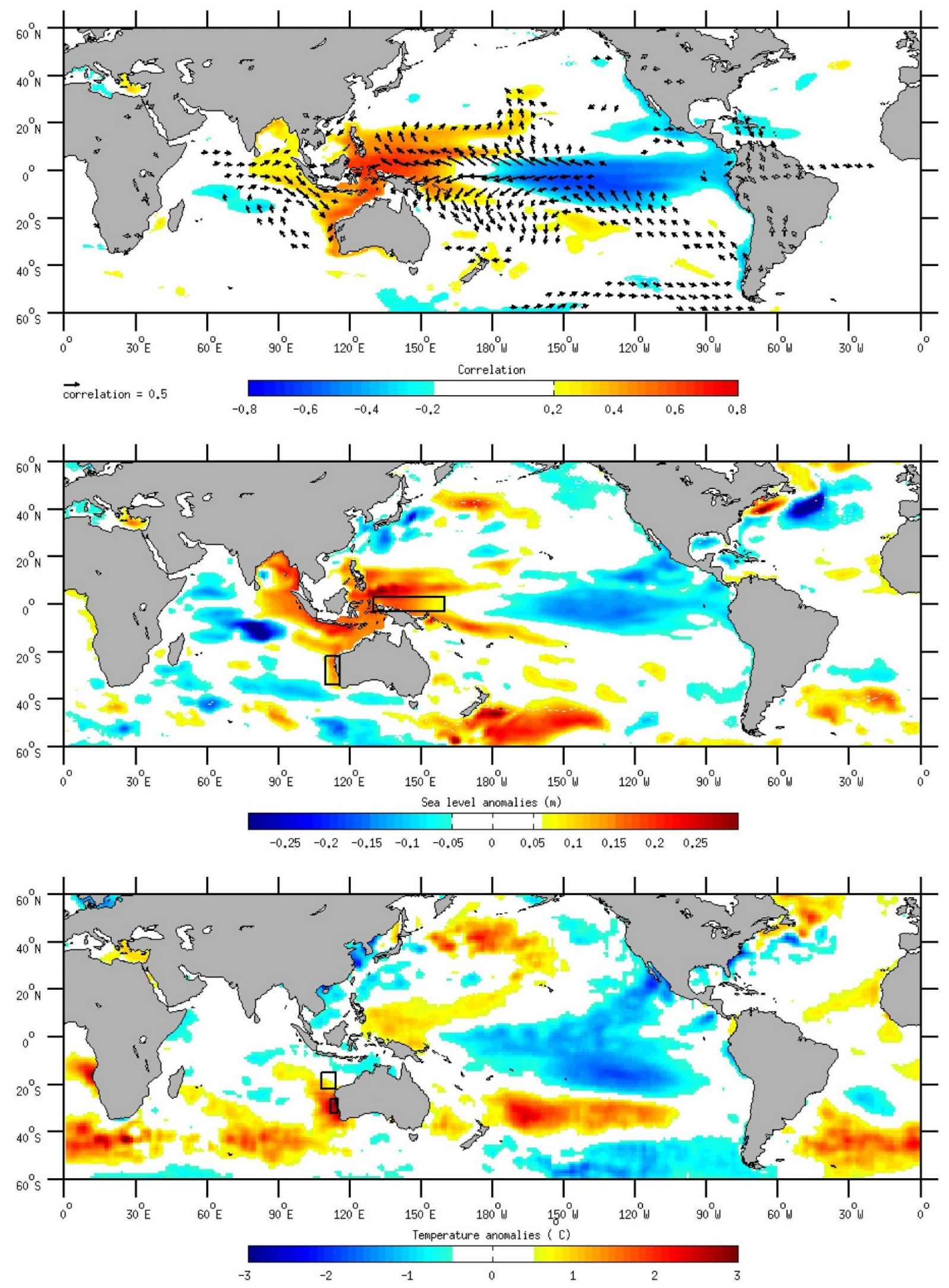

Figure 2 Sea level, sea surface temperature, and wind stress anomalies. (a), One-month lead correlations of Global Ocean Data Assimilation System (GODAS) sea level anomalies (colour shading) and NCEP-DOE reanalysis-2 surface wind anomalies (vector) with Fremantle sea level anomalies (only correlations $>0.3$ are shown). (b), GODAS sea level anomalies averaged between December 2010 and January 2011. (c), Sea surface temperature anomalies averaged between February and March 2011. The boxes in (b) denote the regions in the equatorial Pacific and off the west coast of Australia where average wind anomalies were calculated in Fig. 1b, and the boxes in (c) denotes the regions of average sea surface temperature anomalies used in Fig. 1d and average heat content used in Fig. 1e. 
anomalies in the western Pacific induced high coastal sea level anomalies along the northwest and west coasts of Australia. At the port of Fremantle $\left(32^{\circ} \mathrm{S}\right)$, sea level anomalies are highly correlated with easterly winds and sea levels in the tropical western Pacific at a lag of onemonth (Fig. 2a; Fig. S2). Fremantle sea level, an index for the strength of the Leeuwin Current on interannual time scales ${ }^{18,19}$, peaked at more than $0.2 \mathrm{~m}$ in January-February 2011 (Fig. 1c). In FebruaryMarch 2011, SST anomalies of more than $+2^{\circ} \mathrm{C}$ off the west coast of Australia were the highest since the satellite record dating to 1982 (Fig. 1d; Fig. 2c) and in historical record of in situ observations dating back over 140 years ${ }^{10,13}$.

The 2010-2011 La Niña occurred during a multi-decadal phase since early 1990's of strengthened equatorial easterly winds in the Pacific associated with increased SOI (Fig. 1a), and rising sea levels in the western equatorial Pacific ${ }^{23}$ and off the west coast of Australia (Fig. 1c). There was also a multi-decadal increase since the early 1990's in upper ocean heat content in the southeast Indian Ocean (Fig. 1e), in the region where the pressure head drives the Leeuwin Current and serves as a predictor of the strength of the Leeuwin Current on seasonal time scales ${ }^{24}$. The trend is also reflected in the less pronounced negative heat content anomalies typically occurring in the region during El Niño events over the past decade (e.g. 2002, 2006, and 2009) compared to earlier events (e.g. 1987, 1991-1994, and 1997). Another notable aspect of these inter-decadal variations is the correlation between the equatorial zonal wind anomalies in the Pacific and alongshore winds off the west coast of Australia (Fig. 1b). This correlation was significant and positive (0.53) before 1998, but recently anti-correlations were observed associated with the major La Niñas, of 1998-1999, 2008-2009, and 2010-2011. These prevailing background conditions in the tropical Pacific since the early 1990 's were associated with a negative phase of the Pacific Decadal Oscillation, with a westward shift of the western Pacific warm pool and deep convection ${ }^{25}$, and enhanced westward surface currents west of dateline during La Niña events ${ }^{26}$.

Pacific equatorial winds, Fremantle sea level, and southeast Indian Ocean SST anomalies during the marine heat wave event are more conspicuous when seasonally stratified. The westward wind stress anomaly in September - December 2010 was $0.034 \mathrm{~N} \mathrm{~m}^{-2}$, which exceeded the climatological norm by three standard deviations. The positive Fremantle sea level anomaly was $\sim 0.29 \mathrm{~m}$ in January February 2011, also more than three standard deviations above its seasonal mean (Fig. 3a). The previous record positive sea level anomaly during the same months was only $0.17 \mathrm{~m}$, observed during the 2000 La Niña. The February-March 2011 averaged SST anomaly of $2.7^{\circ} \mathrm{C}$ off the west coast of Australia was well above four standard deviations of its climatological norm, doubling the previous record set in 2000 (Fig. 3b).

Using a linear regression model based on observations between 1982-2010, the January-February 2011 Fremantle sea level and the February-March 2011 SST anomalies were higher than expected given the observed zonal wind stress in the equatorial Pacific at those times. In particular, the sea level anomaly exceeded the linear regression prediction by $0.10 \mathrm{~m}$, more than the standard error of $0.08 \mathrm{~m}$. Also, the SST anomaly exceeded the linear regression prediction by $1.20^{\circ} \mathrm{C}$, more than double the standard error of $0.52^{\circ} \mathrm{C}$ and therefore above $95 \%$ confidence interval ${ }^{27,28}$. The abnormality of the 2011 event was also evident in the magnitude of SST anomalies in February-March 2011 (Fig. 2c) that far exceeded those derived from a linear regression model based on February SOI values (Fig. S3), although the spatial pattern and temporal evolution of the SST anomalies off the Australian coast in the southeast Indian Ocean were similar to those during a typical La Niña (Fig. S1; Fig. S3).

The abnormality of the 2011 Leeuwin Current warming was to a large extent attributed to the unusual seasonal behaviour of the current transports. In a typical seasonal cycle, the Leeuwin Current is strong during austral winter (high Fremantle sea level) and weak
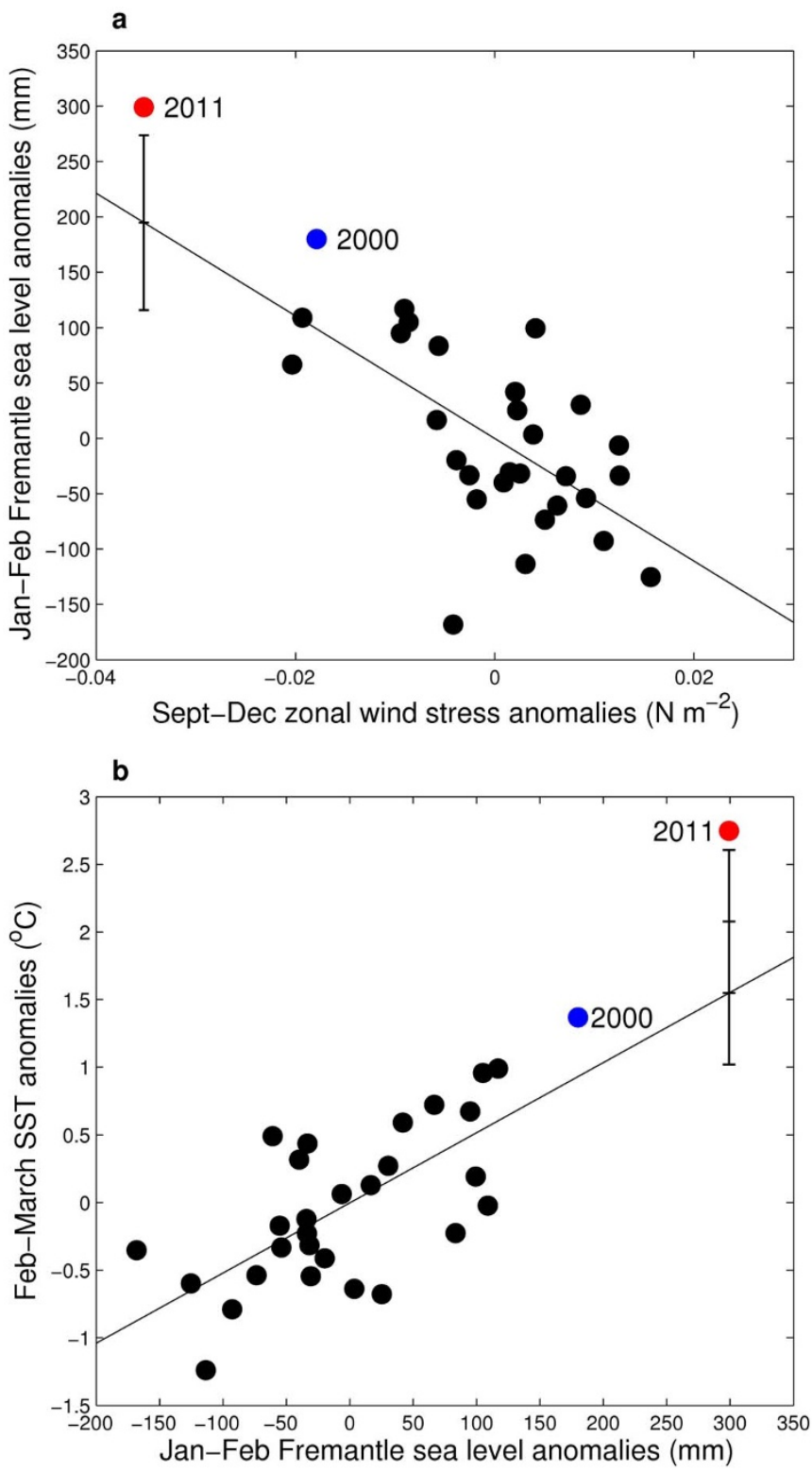

Figure 3 Relationships between equatorial western Pacific zonal wind, Fremantle sea level, and the sea surface temperature anomalies off the west coast of Australia. (a), Scatter plot between September-December averaged zonal wind stress anomalies in the equatorial western Pacific $\left(3^{\circ} \mathrm{S}-3^{\circ} \mathrm{N}, 130^{\circ}-160^{\circ} \mathrm{E}\right)$ and the following January-February averaged Fremantle sea level anomalies during 1982-2011. (b), Scatter plot between January-February averaged Fremantle sea level anomalies and FebruaryMarch averaged sea surface temperature anomalies off the west coast of Australia $\left(32^{\circ}-26^{\circ} \mathrm{S}, 112^{\circ}-115^{\circ} \mathrm{E}\right)$ during $1982-2011$. The thin solid lines denote the linear regression between the indices for all years excluding 2011 , and the standard errors of linear regression predictions for JanuaryFebruary 2011 Fremantle sea level and February-March 2011 temperatures are indicated (two standard error is also denoted for the temperature prediction).

during austral summer (low Fremantle sea level) in response to the opposing southerly winds ${ }^{18,29}$. However, during the austral summer of 2010-2011, both the Fremantle sea level (Fig. 4a) and modelled Leeuwin Current transport (Fig. 4b) had a prominent peak in February 2011. The Leeuwin Current volume transport of $8 \mathrm{~Sv}$ $\left(1 \mathrm{~Sv}=10^{6} \mathrm{~m}^{3} \mathrm{~s}^{-1}\right)$ in February 2011 was unseasonably high compared to a typical winter value of $\sim 5 \mathrm{~Sv}$ (Fig. $4 \mathrm{~b}$ ). The second peak in April 2011, which was still substantially stronger than climatology, 

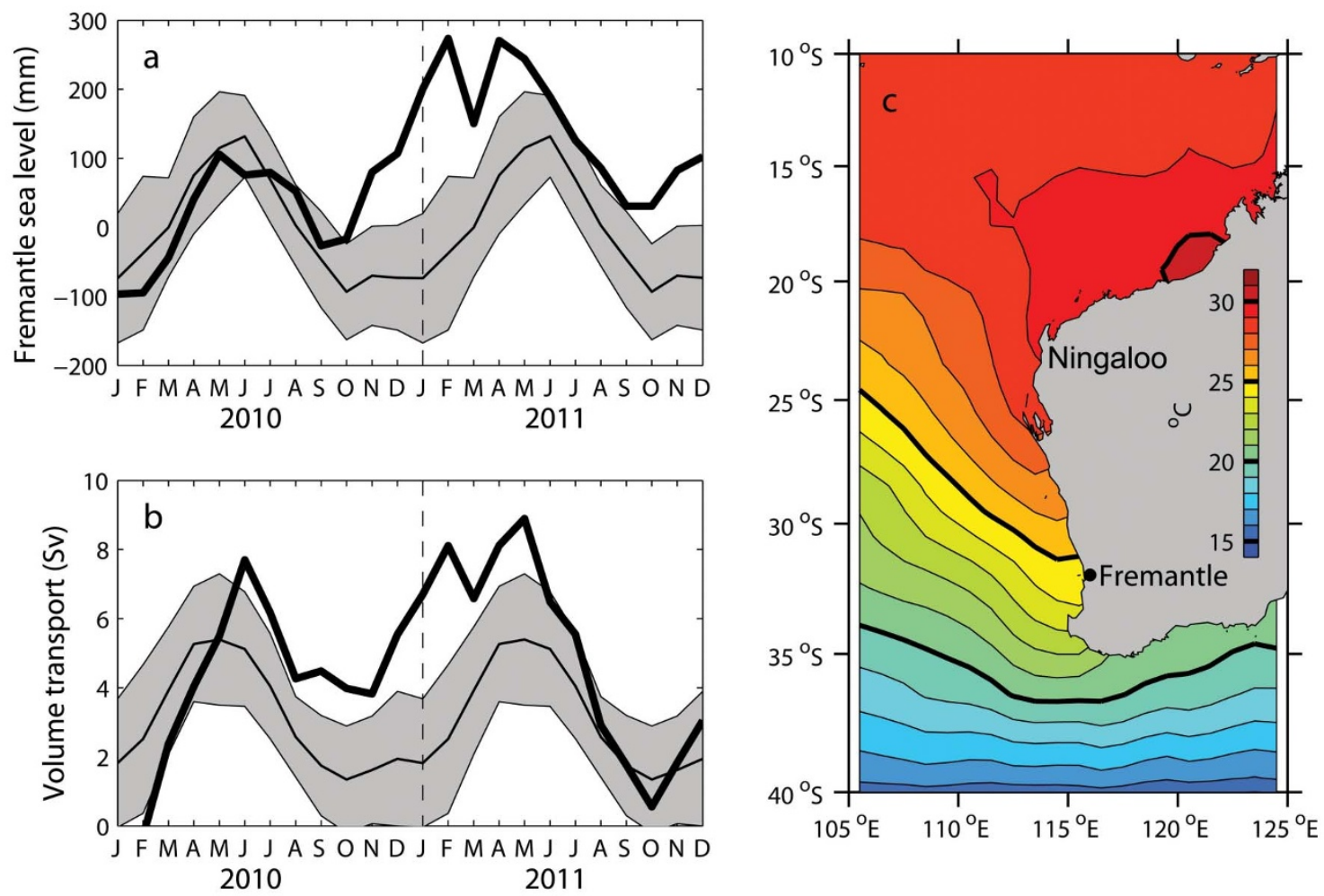

Figure $4 \mid$ Leeuwin Current volume and heat transports. (a), Observed monthly Fremantle sea levels during $2010-2011$ (heavy line). (b), Monthly Leeuwin Current volume transport across $25^{\circ} \mathrm{S}$ during 2010-2011 (heavy line) as derived from Global Ocean Data Assimilation System (GODAS). (c), Sea surface temperature off the Western Australia coast from OISST in February 2011. The light lines and grey shading in (a) and (b) denotes climatology mean and \pm 1 monthly standard deviation.

followed the usual seasonal cycle when the opposing winds abated. Assuming a typical southward Leeuwin Current core velocity within $100 \mathrm{~km}$ of the coast of $0.3 \mathrm{~m} \mathrm{~s}^{-1}$ and alongshore temperature gradient of $6^{\circ} \mathrm{C}$ over $1500 \mathrm{~km}$ in austral summer (Fig. 4c), the anomalous Leeuwin Current transport in February 2011 would warm the coastal region at a rate of $\sim 0.1^{\circ} \mathrm{C}$ per day, or $3^{\circ} \mathrm{C}$ in a month.

The surge of the Leeuwin Current was not only forced by the prolonged easterly wind anomalies in the equatorial western Pacific, but also was furthermore impelled by the reduction of the southerly winds in February 2011 that oppose the alongshore current (Fig. 1b; Fig. S1). The wind anomalies were associated with negative sea level pressure anomalies observed in the southeast Indian Ocean at the peak of the La Niña (Fig. 5), partly due to a Gill type response to the La Niñ $a^{30}$. The negative surface pressure anomalies were displaced westward from the peak SST anomalies off the Australian coast, centred at about $20^{\circ} \mathrm{S}$ in December 2010 and shifted to about $26^{\circ} \mathrm{S}$ in February 2011 (Fig. 5a, 5c). The negative sea level pressure anomalies in February 2011 were more intense than those derived from a linear regression with February SOI (Fig. S3). An atmospheric model forced by observed monthly SST was able to capture the negative sea level pressure anomalies in the southeast Indian Ocean in December 2010, with a weaker magnitude in both sea level pressure and associated wind anomalies (Fig. 5b). The model produced negative pressure anomalies in February 2011, though they were much weaker than observations and the core of the pressure anomalies did not shift southward to $26^{\circ} \mathrm{S}$ which would have a maximum impact on the Leeuwin Current transport (Fig. 5d; Fig. S4).

Intraseasonal variations accompanied the peak of the marine heat wave, which occurred off the west coast of Australia during a twoweek period in 21 February - 6 March 2011 when SST anomalies reached $5^{\circ} \mathrm{C}$ above the 2000-2009 average climatology (Fig. 6a-b). As evident in mooring time series data from the continental shelf, the thermocline dipped in early January, mid-late February and early
April 2011 signifying an intraseasonal strengthening of the Leeuwin Current advection (Fig. 6g). The early January 2011 thermocline dip was consistent with impacts from the Madden Julian Oscillation (MJO) ${ }^{31}$ and may have instigated the warming (Fig. S1) and coral bleaching ${ }^{15}$ at the Ningaloo Reef off northwest Australia in January 2011. The mid-late February deepening that led the sharp SST rise of more than $3^{\circ} \mathrm{C}$ (Fig. 6c) however was not related to MJO forcing ${ }^{32}$ but rather a transient change closely associated with a rapid reduction of southerly winds and a steady rise of air temperature as observed from coastal stations at Rottnest (Fig. 6d-f). Thus, the failure of the atmospheric model to capture the intensity and location of the low pressure system may be related to these intraseasonal variations and local air-sea coupling off the Australian coast.

The reduction of the southerly winds associated with the negative pressure system also caused significant variations of air-sea heat fluxes off the west coast of Australia. Despite differences in detail, most heat flux products indicate significant positive net heat flux anomalies of greater than $50 \mathrm{~W} \mathrm{~m}^{-2}$ into the ocean off the west coast of Australia during February 2011, with most of the contribution coming from reductions in latent and sensible loss to the atmosphere (Fig. S5, S6, S7). A $50 \mathrm{~W} \mathrm{~m}^{-2}$ net heat flux would contribute to a $0.8^{\circ} \mathrm{C}$ temperature increase over a $40 \mathrm{~m}$ thick mixed layer in a month, thus would warm the offshore region where weaker southward flows would be less effective in warming the ocean surface layer. The role of local air-sea heat flux was supported by the fact that the highest warming was trapped in the surface mixed layer $(<40 \mathrm{~m})$ as observed from Argo float data in the offshore area at the peak of the marine heat wave event (Fig. 6h-i). Note that the linear regression between February SOI and net heat flux shows that airsea heat flux tends to damp the warming effects of the La Niña off the northwest Australian coast, and to a lesser extent off the west Australian coast (Fig. S3). However, air-sea heat flux forced rather than damped SST anomalies off the west coast during February 

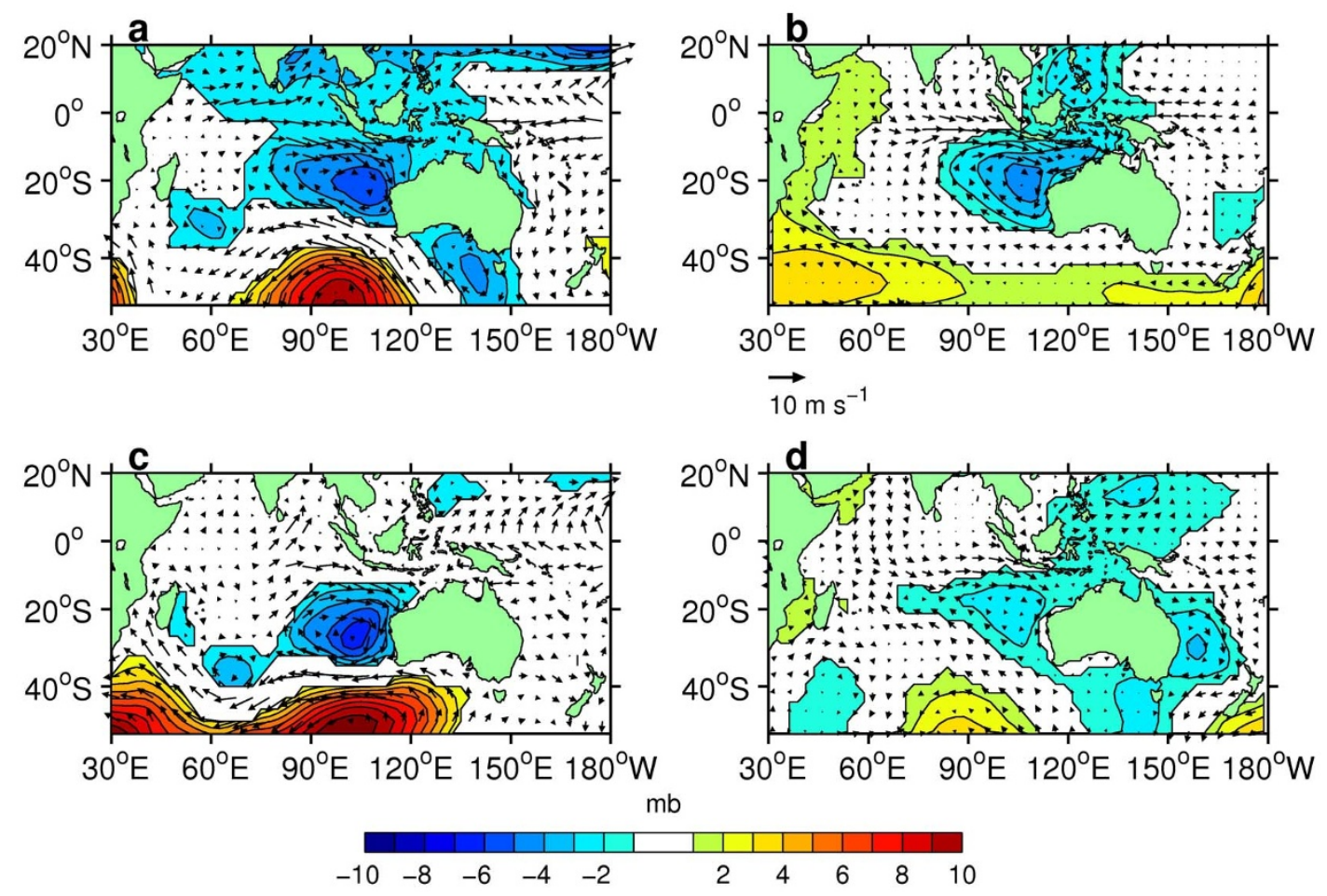

Figure $5 \mid$ Mean sea level pressure anomalies in December 2010 and February 2011. (a), (c), derived from the NCEP-DOE Reanalysis-2, relative to the 1980-2011 average climatology. (b), (d), derived from a 3-member composite of an atmospheric model simulation forced by observed ocean sea surface temperatures. The $925 \mathrm{mb}$ wind anomalies are denoted by arrows.

2011 (Fig. S5), which contributed to the unusualness of this extreme warming event.

\section{Discussion}

Indian Ocean basin warming in the wake of the 2009-2010 El Niño induced strong easterlies along the equator in the western Pacific in mid 2010 and a rapid transition to La Niñ (Fig. 7a). As the La Niña matured, sustained easterly anomalies were at record levels towards the end of 2010 and in early 2011, which forced an oceanic teleconnection from the equatorial western Pacific through the Indonesian straits to the coastal zone of Western Australia, leading to an unseasonable surge of the Leeuwin Current in austral summer (Fig. 1b; Fig. 7a-b). Record northerly wind anomalies off the coast associated with low sea level pressure anomalies (Fig. 1b; Fig. 7b-c), induced by an atmospheric teleconnection from the Indo-Pacific Ocean and reinforced by an intraseasonal variations, further accelerated the Leeuwin Current and reduced turbulent heat loss from the ocean, and caused the extreme warming.

The phase lag ( $\sim 3$ months) between the record easterly anomalies in the equatorial Pacific and the record northerly wind anomalies off the west coast of Australia (Fig. 1b) provided optimal forcing for the unseasonable surge of the Leeuwin Current and the extreme warming event. The climatic drivers of the event included two-way interactions between Indian and Pacific Ocean basins ${ }^{21,33,34}$ through the atmosphere and oceanographically through the Indonesian straits $^{18,35}$. Likewise, interactions spanning intraseasonal to interdecadal time scales were a key feature in the evolution of this extreme event. More research is needed to understand in greater detail how these processes conspired to produce such an unusual warming event. Our analysis provides a conceptual framework for pursuing that research and for making future predictions of similar events.

The significant lag correlations between the SST off the west coast of Australia, coastal sea level, and easterly winds in the equatorial western Pacific (Fig. 3) imply a predictability of Leeuwin Current transport and the warming event one-season in advance. Taking advantage of an ENSO prediction system and using a statistical regression between Fremantle sea level and upper ocean heat content off northwest Australia, the predictability of the Leeuwin Current could have been extended to longer lead times ${ }^{24}$. Still, the magnitude of the unusual 2011 warming event was two standard deviations above that predicted by a linear regression model based on equatorial Pacific zonal wind stress and the Fremantle sea level, indicating that capability of predicting the decadal trends and intraseasonal variations are crucial to improve existing seasonal prediction tools for the region. The cyclonic sea level pressure anomalies off the west coast of Australia were predicted in a coupled ocean-atmospheric model only at short lead times of less than one month (Harry Hendon, personal communication), which substantiates the role of local variability in the evolution of this extreme event and low predictability of its intensity at longer lead time.

The unusual strengthening of Leeuwin Current in 2011 was embedded in multi-decadal trends since the early 1990's of strengthening Pacific trade winds $s^{23,36}$, ocean surface circulation ${ }^{23,37}$, the Indonesian Throughflow and the Leeuwin Current itself ${ }^{35}$. These recent multi-decadal trends may well be part of natural climate variability associated with a La Niña like ocean climate state ${ }^{38}$ that represents a hiatus in global warming ${ }^{39}$. Still, climate model projections suggest that the trade winds should progressively weaken in the tropical Pacific under greenhouse gases forcing ${ }^{40,41}$, resulting in a trend towards lower sea level along the coast of Western Australia relative to the global mean ${ }^{42}$ and a weakened Leeuwin Current ${ }^{43}$. There are also suggestions that occurrences of extreme ocean temperatures off the Western Australia coast had been declining based on the 30-year satellite SST record up to $2010^{44}$. Thus, it is imperative to effectively communicate the distinctions between climate change and decadal climate variability so that events like the 2011 marine heat wave are properly understood and appropriate steps can be taken to mitigate the impacts of extreme warming events in the future.

As a final note, the interannual SST warming off the west coast of Australia may be termed a "Ningaloo Niño", in analogy to other 

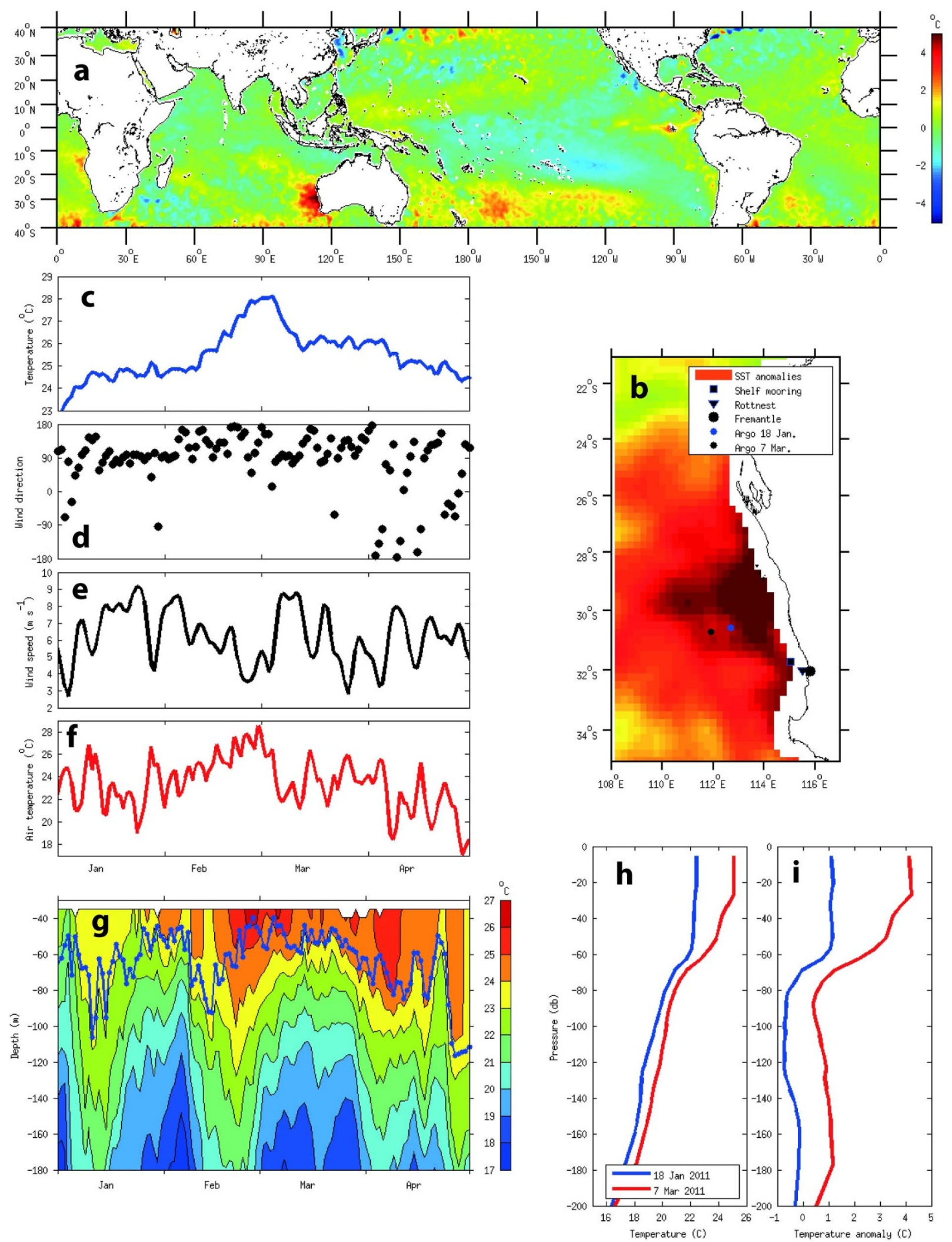

Figure 6 Ocean temperatures at the peak of the extreme warming event. (a), Sea surface temperature anomalies during 21 February - 6 March 2011 at the peak of the extreme warming event. (b), A zoomed-in view of the temperature anomaly pattern off the west coast of Australia. (c), Daily sea surface temperature during January - April 2011 for the region off the west coast of Australia (averaged over $\left.28^{\circ}-32^{\circ} \mathrm{S}, 112^{\circ}-115^{\circ} \mathrm{E}\right)$. (d), (e), wind direction and speed at the coastal station on the Rottnest Island. 180 denote southerly winds so that the winds are dominantly southeastlies. (f), Daily air temperatures measured at the coastal station on the Rottnest Island. (g), Moored temperature observations on the continental shelf off Western Australia coast $\left(31^{\circ} 59.0^{\prime} \mathrm{S}, 115^{\circ} 14.0^{\prime} \mathrm{E}\right)$. The blue dotted line denotes the surface mixed layer depth (defined as $0.5^{\circ} \mathrm{C}$ from the surface temperature). (h), Temperature profiles observed before (18 January 2011) and at the peak ( 7 March) of the maximum temperature anomalies observed from an Argo float located to the west of the warming centre. (i), Temperature anomalies of the Argo profiles from the CSIRO Atlas of Regional Seas (CARS) climatology. The locations of Rottnest Island, Fremantle, shelf mooring and Argo profiles are denoted in (b). 
a, May 2010

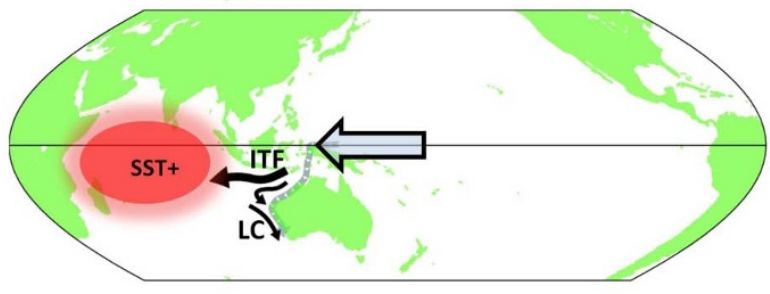

b, December 2010

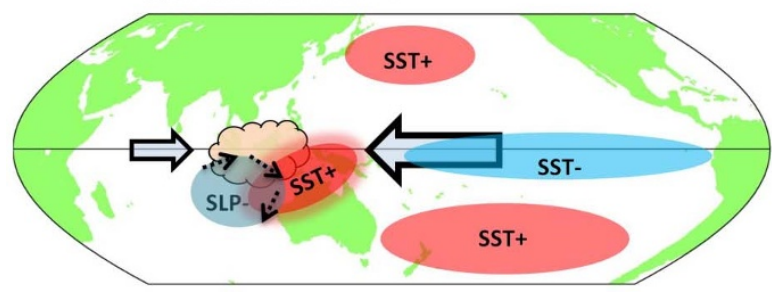

c, February 2011

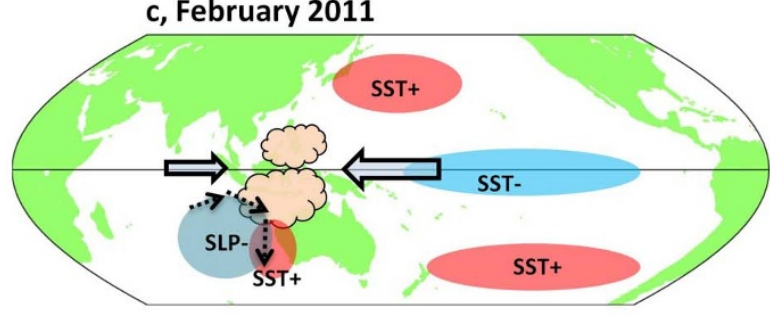

Figure 7 | Schematic of the 2010-2011 La Niña influences on the Western Australia coast. (a), May 2010 when the Indian Ocean basin warming after the 2009-2010 El Niño event induced easterly wind anomalies in the equatorial western Pacific, which led to the quick transition from El Niño to La Niña conditions in the tropical Pacific. (b), December 2010 at the peak of the La Niña event. (c), February 2011 at the peak of the extreme warming event off the west coast of Australia. The red and blue areas denote the main positive and negative SST anomalies in the Pacific and Indian Ocean; the light blue areas denote low sea level pressure anomalies in the southeast Indian Ocean and the dashed arrows are the associated wind anomalies; the large arrows denote zonal wind anomalies along the equator in the Pacific and Indian Oceans. In (a), the ocean surface currents in the southeast Indian Ocean are sketched (ITF: Indonesian Throughflow; LC: Leeuwin Current) and the gray curved arrows in the top panel denote the equatorial and coastal waveguides through which the equatorial Pacific wind anomalies affect the strength of the Leeuwin Current. The clouds in (b) and (c) denote the locations of atmospheric deep convection related to the La Niña as shown in outgoing longwave radiation data ${ }^{55}$.

eastern boundary current warming phenomena such as El Niño in the Pacific and Benguela Niño in the Atlantic. Ningaloo Reef off the North West Cape of Australia is famed for its rich corals, whale sharks, and other marine life, and the reef and surrounding area are listed as world heritage by the United Nation. It is also the source region of the Leeuwin Current. Derived from the aboriginal Gnulli language, Ningaloo means promontory (Source: Australian Geographic October-December 2006), shaped like a beckoning finger of nearly $200 \mathrm{~km}$ long and jutting into the Indian Ocean (Fig. 4c). Due to the low latitude pathway from the Pacific to the Indian Ocean ${ }^{17,45}$, a Ningaloo Niño often occurs during a La Niña event of the Pacific when the easterly winds in the equatorial western Pacific drive a stronger Leeuwin Current transport ${ }^{18}$. Ningaloo Niño, represented by SST averaged in the area of $32-26^{\circ} \mathrm{S}, 112-115^{\circ} \mathrm{E}$, is moderately correlated with SOI at 0.35 for the period of 1980-2011. Other processes, such as air-sea heat fluxes and upper ocean heat storage are important for the amplitude of the Ningaloo Niño SST variability $^{19}$. The 2011 marine heat wave is a rather unique Ningaloo Niño event due to the unusual alignment of intraseasonal to interdecadal processes, resulting in an unseasonable surge of the Leeuwin Current and the extreme warm condition in austral summer 2011.

\section{Methods}

Observational datasets and reanalysis model products. Monthly NOAA Optimum Interpolation (OI) sea surface temperature (SST) data ${ }^{46}$ is a combined product of satellite and in situ observations from 1982 to present. Daily Tropical Rainfall Measuring Mission (TRMM) Microwave Imager (TMI) SST product ${ }^{47}$ is available from 1998 to present. The National Centers for Environmental Prediction (NCEP) Department of Energy (DOE) reanalysis-2 sea level pressure, $925 \mathrm{mb}$ wind, and airsea heat fluxes products ${ }^{48}$ is available from 1979 to present. Monthly Tropflux wind stress and air-sea heat fluxes products ${ }^{49}$ covered $30^{\circ} \mathrm{S}-30^{\circ} \mathrm{N}$ for the period of 1979 2011. The Southern Oscillation Index (SOI) was obtained from the Australia Bureau of Meteorology and the Niño 3.4 SST was derived from Extended Reconstructed SST $(\text { ERSST v3b })^{50}$. Fremantle sea level was obtained from the University of Hawaii Sea Level Center. The NOAA Global Ocean Data Assimilation System (GODAS) ocean temperature, current, and air-sea heat fluxes products ${ }^{51}$ covered the period of 1980 present. Argo float data were processed by the CSIRO Marine and Atmospheric Research and the shelf mooring data were maintained by the Integrated Marine Observing System (IMOS). CSIRO Atlas of Regional Seas (CARS) temperature climatology version $2009^{52}$ was used to derive Argo temperature anomalies. Altimeter sea level anomaly data were obtained from gridded product Archiving, Validation, and Interpretation of Satellite Oceanographic Data (AVISO) ${ }^{53}$. Monthly and daily values of the air-sea heat flux were derived from the European Centre for MediumRange Weather Forecasts (ECMWF) interim re-analysis ${ }^{54}$. Outgoing longwave radiation images were obtained from the NOAA Climate Prediction Center monthly ocean briefing ${ }^{55,56}$.

Model experiment. We used a hydrostatic finite difference atmospheric model, with staggered horizontal Arakawa B grid of $2^{\circ}$ latitude and $2.5^{\circ}$ longitude and a 24 level vertical hybrid coordinate grid ${ }^{57}$. Sigma coordinates were used near the surface, which gradually shifted to pressure surfaces above the $250 \mathrm{mb}$ level, with the top at about $40 \mathrm{~km}$. To resolve boundary layer, the model has 9 full levels below $1.5 \mathrm{~km}$. Radiation takes into account the diurnal cycle and the effect of halocarbons, water vapour, $\mathrm{CO}_{2}$, ozone, methane and nitrous oxides. Shortwave radiation incorporates an exponential sum fit with 18 bands, and liquid and ice cloud radiation effects. Longwave radiation is based on simplified exchange approximation, which accounts for absorption and emission of major principal gases ( $\mathrm{H} 2 \mathrm{O}, \mathrm{CO} 2, \mathrm{O} 3, \mathrm{~N} 2 \mathrm{O}, \mathrm{CH} 4$, halocarbons). The effect of aerosols is taken into account in radiation routine as well. Cumulus parameterization is based on relaxed Arakawa-Schubert formulation where convection is taken as a spectrum of entraining plumes. The underlying SST forcing for the model experiments is taken from daily Optimal Interpolation (OI) SST version 2 data set (AVHRR only product) ${ }^{46}$, which is distributed by NOAA National Climatic Data Center. Monthly SST fields were constructed from daily maps. In the model experiment, the SST forcing was taken as global monthly SST values. The experiment consisted of an ensemble of 3 members from January 2005 to December 2011. The difference between members was in the initial conditions, based on NCEP reanalysis data on 1 January 2004, 2005 and 2006 respectively. The results from the 3 members were averaged to derive a composite and the 2011 anomaly fields were calculated from the 2005-2010 model climatology.

1. Walther, G. R. et al. Ecological responses to recent climate change. Nature 416, 389-395 (2002).

2. Sexton, J. P., McIntyre, P. J., Angert, A. L. \& Rice, K. J. Evolution and ecology of species range limits. Annu. Rev. Ecol. Evol. Syst. 40, 415-436 (2009).

3. Conover, D. O. \& Present, T. M. C. Countergradient variation in growth rate: compensation for length of the growing season among Atlantic silversides from different latitudes. Oecologia 83, 316-324 (1990).

4. Byrne, M. Impact of ocean warming and ocean acidification on marine invertebrate life history stages: vulnerabilities and potential for persistence in a changing ocean. Oceanogr. Mar. Biol. Ann. Rev. 49, 1-43 (2011).

5. Peck, L. S., Webb, K. E. \& Bailey, D. M. Extreme sensitivity of biological function to temperature in Antarctic marine species. Functional Ecology 18, 625-630 (2004).

6. Stenseth, N. C. et al. Ecological effects of climate fluctuations. Science 297, 1292-1296 (2002).

7. Hoegh-guldberg, O. Climate change, coral bleaching and the future of the world's coral reefs. Mar. Freshwat. Res. 50, 839-866 (1999).

8. Lough, J. M. 1997-1998: Unprecedented thermal stress to coral reefs? Geophys. Res. Lett. 27, 3901-3904 (2000).

9. Marba, N. \& Duarte, C. M. Mediterranean warming triggers seagrass (Posidonia oceanica) shoot mortality. Global Change Biology 16, 2366-2375 (2010).

10. Pearce, A. et al. The "marine heat wave" off Western Australia during the summer of 2010/11. Fisheries Research Report No. 222. Department of Fisheries, Western Australia. 40pp (2011). 
11. Pearce, A. F. \& Feng, M. The rise and fall of the "marine heat wave" off Western Australia during the summer of 2010/11. Journal of Marine Systems 111-112, 139-156 (2013).

12. Thomson, D. P., Bearham, D., Graham, F. \& Eagle, J. V. High latitude, deeper water coral bleaching at Rottnest Island, Western Australia. Coral Reefs 30, 1107-1107 (2011).

13. Wernberg, T. et al. An extreme climatic event alters marine ecosystem structure in a global biodiversity hotspot. Nature Climate Change (2012).

14. Abdo, D. A., Bellchambers, L. M. \& Evans, S. N. Turning up the Heat: Increasing Temperature and Coral Bleaching at the High Latitude Coral Reefs of the Houtman Abrolhos Islands. PLoS ONE 7(8), e43878 (2012).

15. Depczynski, M. et al. Bleaching, coral mortality and subsequent survivorship on a West Australian fringing reef. Deep-sea Res. Part II, in press (2012).

16. Cresswell, G. R. \& Golding, T. J. Observations of a southward flowing current in the south-eastern Indian Ocean. Deep-Sea Res. 27A, 449-466 (1980).

17. Clarke, A. J. \& Li, J. El Niño/La Niña shelf edge flow and Australian western rock lobsters. Geophys. Res. Lett. 31, L11301 (2004).

18. Feng, M., Meyers, G., Pearce, A. \& Wijffels, S. Annual and Interannual Variations of the Leeuwin Current at $32^{\circ}$ S. J. Geophys. Res. 108(11), 3355 (2003).

19. Feng, M., Biastoch, A., Boning, C., Caputi, N. \& Meyers, G. Seasonal and interannual variations of upper ocean heat balance off the west coast of Australia. J. Geophys. Res. 113, C12025 (2008).

20. Black, E. et al. Factors contributing to the summer 2003 European Heatwave. Weather 59, 217-222 (2004).

21. Kim, W. et al. The unique 2009-2010 El Niño event: A fast phase transition of warm pool El Niño to La Niña. Geophys. Res. Lett. 38, L15809 (2011).

22. Sandery, P. Significant mesoscale oceanography: summer 2010/2011. Bull. Aust. Met. Oceanogr. Soc. 24, 48-49 (2011).

23. Feng, M., McPhaden, M. J. \& Lee, T. Decadal variability of the Pacific subtropical cells and their influence on the southeast Indian Ocean. Geophys. Res. Lett. 37, L09606 (2010).

24. Hendon, H. H. \& Wang, G. Seasonal prediction of the Leeuwin Current using the POAMA dynamical seasonal forecast model . Clim. Dynam. 34, 1129-1137 (2009).

25. Cai, W. \& van Rensch, P. The 2011 southeast Queensland extreme summer rainfall: A confirmation of a negative Pacific Decadal Oscillation phase? Geophys. Res. Lett. 39, L08702 (2012).

26. Shinoda, T., Hurlburt, H. E. \& Metzger, E. J. Anomalous tropical ocean circulation associated with La Niña Modoki. J. Geophys. Res. 116, C12001 (2011).

27. Weisberg, S. Applied linear regression, $2^{\text {nd }}$ ed., John Wiley, New York, 324pp (1985).

28. Wilks, D. S. Statistical methods in the atmospheric sciences. Academic Press, 467pp (1995).

29. Smith, R. L., Huyer, J., Godfrey, S. \& Church, J. The Leeuwin current off Western Australia, 1986-1987. J. Phys. Oceanogr. 21, 323-345 (1991).

30. Gill, A.. E. Some simple solutions for heat induced tropical circulation. Quart. J. Roy. Meteor. Soc. 106, 447-462 (1980).

31. Marshall, A. \& Hendon, H. H. Impacts of the MJO in the Indian Ocean and on the Western Australian coast. Clim. Dynam. under revision, (2012).

32. Wheeler, M. C. \& Hendon, H. H. An all-season real-time multivariate MJO index: development of an index for monitoring and prediction. Mon. Wea. Rev. 132, 1917-1932 (2004)

33. Xie, S.-P. et al. Indian Ocean Capacitor Effect on Indo-Western Pacific Climate during the Summer following El Niño. J. Climate 22, 730-747 (2009).

34. Yang, J. et al. Impact of the Indian Ocean SST basin mode on the Asian summer monsoon. Geophys. Res. Lett. 34, L02708 (2007).

35. Feng, M. et al. The reversal of the multi-decadal trends of the equatorial Pacific easterly winds, and the Indonesian Throughflow and Leeuwin Current transports. Geophys. Res. Lett. 38, L11604 (2011).

36. Merrifield, M. A. \& Maltrud, M. E. Regional sea level trends due to a Pacific trade wind intensification. Geophys. Res. Lett. 38, L21605 (2011).

37. Qiu, B. \& Chen, S. Multidecadal Sea Level and Gyre Circulation Variability in the Northwestern Tropical Pacific Ocean. J. Phys. Oceanogr. 42, 193-206 (2012).

38. Meehl, Gerald, A. et al. Model-based evidence of deep-ocean heat uptake during surface-temperature hiatus periods. Nature Climate Change 1(7), 360 (2011)

39. Easterling, D. R. \& Wehner, M. F. Is the climate warming or cooling? Geophys. Res. Lett. 36, L08706 (2009).

40. Vecchi, G. A. et al. Weakening of tropical Pacific atmospheric circulation due to anthropogenic forcing. Nature 441, 73-76 (2006).

41. Collins, M. et al. The impact of global warming on the tropical Pacific Ocean and El Niño. Nature Geoscience 3, 391-397 (2010).
42. Tokinaga, H. et al. Regional patterns of tropical Indo-Pacific climate change: Evidence of the Walker Circulation weakening. J. Climate 25, 1689-1710 (2012).

43. Sun, C. et al. Marine Downscaling of a Future Climate Scenario for Australian Boundary Currents. J. Climate 25, 2947-2962 (2012).

44. Lima, F. P. \& Wethey, D. S. Three decades of high-resolution coastal sea surface temperatures reveal more than warming. Nature Commun. 3 (2012).

45. Yamagata, T. et al. Coupled ocean-atmosphere variability in the tropical Indian Ocean. Earth's Climate: The Ocean-Atmosphere Interaction Geophys. Monogr. Vol. 147, Amer. Geophys. Union., 189-211 (2004).

46. Reynolds, R. W. et al. An improved in situ and satellite SST analysis for climate. J. Climate 15, 1609-1625 (2002)

47. Gentemann, C. et al. Diurnal signals in satellite sea surface temperature measurements. Geophys. Res. Lett. 30(3), 1140-1143 (2003).

48. Kanamitsu, M. et al. NCEP-DOE AMIP-II Reanalysis (R-2). Bull. Amer. Meteor. Soc. 83, 1631-1643 (2002).

49. Kumar, P. et al. TropFlux: Air-Sea Fluxes for the Global Tropical Oceans Description and evaluation. Clim. Dynam. 38, 1521-1543 (2012).

50. Smith, T. M. et al. Improvements to NOAA's Historical Merged Land-Ocean Surface Temperature Analysis (1880-2006). J. Climate 21, 2283-2296 (2008).

51. Behringer, D. W., Ji, M. \& Leetmaa, A. An improved coupled model for ENSO prediction and implications for ocean initialization. Part I: The ocean data assimilation system. Mon. Wea. Rev. 126, 1013-1021 (1998).

52. Ridgway, K. R., Dunn, J. R. \& Wilkin, J. L. Ocean interpolation by fourdimensional least squares -Application to the waters around Australia. J. Atmos. Ocean. Tech. 19, 1357-1375 (2002).

53. Ducet, N., Le Traon, P. Y. \& Reverdin, G. Global high-resolution mapping of ocean circulation from TOPEX/Poseidon and ERS-1 and -2. J. Geophys . Res. 105(C8), 19477-19498 (2000).

54. Berrisford, P. et al. The ERA-Interim archive version 2.0. Technical Report, ERA Report Series 1, ECMWF, Shinfield Park, Reading UK (2011).

55. http://www.cpc.ncep.noaa.gov/products/GODAS/ (accessed 20 June 2012).

56. NOAA Satellite and Information Service (NESDIS) Outgoing Long-wave Radiation images were obtained from Climate Prediction Center Monthly Ocean Briefing.

57. The GFDL Global Atmospheric Model Development Team. The new GFDL global atmosphere and land model AM2-LM2: Evaluation with prescribed SST simulations. J. Climate 17(24), 4641-4673 (2004).

\section{Acknowledgements}

This research is partly supported by the CSIRO Wealth from Oceans Flagship, the Western Australia Marine Science Institution, the Integrated Marine Observing System, the Fisheries Research and Development Corporation, NOAA's Climate Program Office, and NSF. The authors would thank Harry Hendon for constructive comments on an early version of the paper. MF would thank Toshio Yamagata and Swadhin Behera for discussions on the Ningaloo Niño terminology. All the maps in the paper are produced by M_Map software in matlab, which uses GSHHG - A Global, Self-consistent, Hierarchical, High-resolution Geography Database, under GNU Lesser General Pubic License. PMEL contribution number 3952

\section{Author contributions}

All the authors contributed to designing the research, interpreting results, and writing the paper. MF analysed the observation data and ocean model output, and $\mathrm{JH}$ performed the atmospheric model runs.

\section{Additional information}

Supplementary information accompanies this paper at http://www.nature.com/ scientificreports

Competing financial interests: The authors declare no competing financial interests.

License: This work is licensed under a Creative Commons Attribution-NonCommercial-NoDerivs 3.0 Unported License. To view a copy of this license, visit http://creativecommons.org/licenses/by-nc-nd/3.0/

How to cite this article: Feng, M., McPhaden, M.J., Xie, S. \& Hafner, J. La Niña forces unprecedented Leeuwin Current warming in 2011. Sci. Rep. 3, 1277; DOI:10.1038/ srep01277 (2013) 